\title{
MEMORIA, MORALITY, AND MNEMONIC HEGEMONY OF ROMAN EMPERORS
}

\begin{abstract}
The importance of memory in the formation of identity cannot be overestimated. This goes for individuals, but also for collective bodies. As a multifaceted and multidimensional phenomenon, memory in a retrospective way preserves past events, which contributes to explain and construct the present, but also has prospective claims. This makes memory a powerful force to construct or demolish identities in several domains (for example, political, social, cultural), on several levels (such as private and public; individual and collective), and in various time frames (past, present, future). This article focuses on the capacity of posthumous memory to serve as a locus for negotiation, confirmation, competition, and contestation of political power by mnemonic hegemons. The main point I aim to make is that mnemonic hegemons could 'collectificate' (= make into a collective issue) (personal) rivalry over power by turning it into a collective issue. Negative posthumous commemoration was one of the mechanisms put in play here. The intended effect was to frame a distinction between the victor/we/state and the victim/ anti-social he. How it worked out, depended on the power balance. Two cases, one from the early Imperial period, and one dating to the early third century, when the imperial system had become institutionalized, will be discussed to demonstrate such collectification of commemoration, and which explicit and implicit information about the power balance this implied.
\end{abstract}

Keywords: Memory sanctions; mnemonic hegemony; morality; legitimation; Roman Principate.

\section{MEMORY, IDENTITY AND THE IMPORTANCE OF MEMORIA IN ROMAN CULTURE}

$\mathbf{M}$ emories from the past constitute humanity in the present. An unambiguous definition of 'memory', however, is not easily given. ${ }^{1}$ Memory is a complex phenomenon that functions on several levels and can be approached from different viewpoints. Memory in an active sense denotes the capacity to remember, or a product of that activity, for instance knowledge, experience or an impression, resulting from past actions and events. Memory can be approached from different disciplinary angles, each with its own set of questions, methodology, and functional models. In biology or psychology, for example, memory is studied for its biological substance and evolution of the brain, and its technical functioning. ${ }^{2}$ From ${ }^{1}$ Definitions of 'memory' abound. One example is the definition by SUTTON 2012. Sutton labels a diverse set of cognitive capacities by which we retain information and reconstruct past experiences, usually for present purposes." For Roman historical memory, see for example GALINSKY 2014; GALINSKY/LAPATIN 2015.

2 For memory as a biological-evolutionary phenomenon, enabling humanity to survive thanks to empirical knowledge, see for instance NAIRNE/PANDEIRADA/THOMPSON 2008, 176-180. For parallels between biological and cultural functions of memory, see for instance MESOUDI/
Janneke de Jong

Radboud University Nijmegen j.h.m.deJong@let.ru.nl

DOI: $10.14795 /$ j.v6i3.445

ISSN 2360 - 266X

ISSN-L 2360 - 266X 
a point of view taken from social sciences, the role of memory is examined as a defining aspect of human behavior and of (social) identity formation. ${ }^{3}$ Memory is also a recurring topic in historical studies, as sources from the past offer the opportunity to study the mechanisms and media of commemoration in past societies. ${ }^{4}$ This contribution will discuss two particular instances from Roman history of political equals rivalling each other, resulting in the contestation of the rival's commemoration by the victor for the ideological purpose of legitimation of power by the victor. The fundamental assumption of this contribution is based upon Harriet Flower's demonstration that memory - especially negative uses of a rival's memory - in political contexts is an important tool for legitimatization of the victor's power position in combination with Berthold Molden's concept of mnemonic hegemony. ${ }^{5}$ According to Molden: 'Ruling groups achieve this [sc. a culturally agreed-on power position] only by blocking out the fact that historical events might always have turned out different or by claiming that any different outcome would be a worse-case scenario. They stabilize power by the successful establishment of a supposedly teleological and linear historical narration. This constitutes a characteristic of collective remembrance. ${ }^{6}$ This idea has explanatory force, which in my view is applicable to the two cases to be discussed. From Molden's concept of mnemonic hegemony, I have borrowed two aspects for my discussion of the case studies': 1) 'discursive agency in specific political contexts (interests)'; 2) closely connected to this is 'access to means of communication and spheres of social knowledge production and signification.' A third aspect, that of the 'passive reception by society' and 'public adscription of narrative credibility' may also be applicable, but my focus here is on the agents, not on the audience(s). The result, however, is the same: nothwithstanding the contents of the accounts given (they present 'their' truth), due dominant narrative having the upper hand in the creation of collective memory is that which originates from the persons in power. ${ }^{8}$ The question of this paper is whether Molden's concept of mnemonic hegemony might work for Roman history as well, where politics and public commemoration were strongly interconnected. Roman history offers good ground to explore these questions, because of the importance of memoria for Roman society and the many examples of sanctions against memory that are known from a variety of ancient sources. In the cultural context of Roman history, memoria was strongly

WHITEN/LALAND 2004, 1-11.

3 Important contributors to the conceptualization of memory are the sociologist Maurice Halbwachs and the art historian Aby Warburg. In the 1920s, approaching memory from their own expertise, they came to comparable conclusions about the role of memory in processes of formation of groups and group identity. For a brief overview of this, see ASSMANN 2008.

4 Cf. KLEIN 2000; RICOEUR 2004; TUMBLETY 2013. More general on memory studies as an (emerging) academic field are TAMM 2013; SEGESTEN/WÜSTENBERG 2017. Cf. also the emergence of journals such as History \& Memory. Studies in Representation of the Past (since 1989) and Memory Studies (since 2008) and of handbooks, for instance by TULVING/ CRAIK 2000; and by TOTA/HAGEN 2015. For the relation between memory and media, cf. ASSMANN/WEINBERG/WINDISCH 1998.

5 FLOWER 2006.

${ }^{6}$ MOLDEN 2015, 127.

MOLDEN 2015, 127.

${ }^{8}$ MOLDEN 2015, 129. related to esteem and good reputation, which in itself was related to political activity and public acknowledgement. Roman aristocratic families, from whose circles the political leaders came, were much concerned with acquiring and keeping up their good reputation over generations. ${ }^{9}$ As the leaders were expected to display exemplary behavior, there is even a strong moral dimension to the use of this. ${ }^{10}$ Having a good reputation was even useful beyond life: descent from honorable ancestors was beneficial for the social standing and the political opportunities for individual elite members. From this it is clear that public visibility, political activity and morality constitute different, yet interconnected, aspects of memory in Roman history.

In what follows, I will discuss two cases taken from Roman history, that illustrate how personal memory was strategically used in Roman political history: Augustus versus his opponents in the civil wars following the murder of Julius Caesar, and Caracalla versus Geta. The presentation of sources is very selective. Rather than giving a comprehensive analysis of all sources available, I have only used two texts: fragments of the Res Gestae Divi Augusti and a fragmentary papyrus text, preserving an imperial edict by Caracalla. The choice for these cases and texts results from the given that these are statements in words chosen by the victors themselves. Hence, they illustrate the discursive agency and access to and control of communication media. Moreover, these cases concern political battles in which a comparable mechanism of dealing with the memory of rivals applies, even if they are situated within a different political setting: whereas the first case is situated during a transformational phase in which the Republican system transformed into an imperial system, the second case is situated in a time when the emperorship had become an institution. ${ }^{11}$ They furthermore correspond in that each case the victor publicly demeaned a political contestant who held a more or less equal power position at the time of their conflict. Concerning the reception of the messages it may be remarked that they were accepted in the sense that they became part of the public sphere. The $R G D A$ was publicly visible in Rome and at least some copies were dispersed in the empire, whereas the result of granting Roman citizenship was, for instance, clear in people taking on the name Aurelius.

In the discussion of these cases, it will be pointed out how political use of memory functioned in opposite ways for the victor and the victim and how use of memory sanctions added a moral and legitimizing dimension to the political outcome. The moral dimension of acting in the interest of the state was a recurring argument used by the victor in his presentation of events, and vice versa that the rival was depicted as amorally endangering the state. The involvement of the state was an important aspect of the discourse of public commemoration, by which rivalry on the individual level ${ }_{9}$ VARNER 2004, 2; FLOWER 2006; VAN DEN HENGEL 2009, 322.

${ }^{10}$ This results from Roman interest in 'moral rectitude', as labeled by FLOWER 2006, 44. Roman preoccupation with exemplary behavior was made manifest for instance in the practice of eulogies or placement of honorary statues. For statuary as communicators of virtue, cf. for example LÖHR 2006; VAN DEN HENGEL 2009, 97-99.

${ }^{11}$ FLOWER (2006), 110, points to new political behavior in comparison with earlier Republican practices: 'The new political game was a zero-sum game in which one side aimed to prevail by the complete erasure and defeat of its political opponents.' 
was transformed into a matter of collective importance. In both cases the political victors can be qualified as mnemonic hegemons: although their version of history may not have been embraced unanimously by all members of society, their dominant position enabled them to publicly communicate their side of the story, in such a way that it became the dominant version. ${ }^{12}$

\section{MEASURES AGAINST MEMORIA: A BRIEF OVERVIEW}

Given the importance of memoria it is not surprising that prominent Romans from early on took great efforts to preserve their name and deeds for posterity. Resulting from this importance of public (self-) presentation and the wish to maintain the power balance, the nobility made agreements on public commemoration practices. By making consensual agreements about who could be honored how, where, and when, no individual or family could present himself limitlessly. ${ }^{13}$ This course of action functioned well for a small city state, but resulting from Rome's expanded domination of Italy and large parts of the Mediterranean since the third century BCE, competition between the nobiles about political and military posts grew fiercer as did competition about public visibility and public memory space. As a result, public visibility increasingly became a political instrument that worked in two directions: it was a means to elevate oneself and to diminish the public presence of one's rival. It goes without saying, then, that preserving one's (family's) reputation and memory was among a Roman nobilis' priorities. But reputation and memory could also become object of attack, both during lifetime and posthumously. ${ }^{14}$ Indeed, Rome's history has preserved numerous examples of persons whose memory was inflicted posthumously by various punitive and dishonoring measures. ${ }^{15}$ That punitive and disgracing sanctions were usually decided for people who were judged to have misbehaved against the state is telling for the nature of Roman society. The nobiles could declare them dissident or even officially designate them 'enemy of the state' (hostis). This declaration in many cases anticipated posthumous sanctions targeting the victim's reputation and economic situation. Such sanctions are often referred to by the term damnatio memoriae. ${ }^{16}$

\footnotetext{
12 Cf. MOLDEN 2015, 128.

13 FLOWER 2006, 51-55.

14 For the notion that this should be placed in the context of a culture of honor and shame, cf. FLOWER 1996; FLOWER 2006, 7-8.

15 Examples of measures against memoria are found in Rome's earliest history and represent a universal phenomenon also encountered in other ancient cultures from the Near Eastern and the Mediterranean world. See FLOWER 2006, 17-41; VARNER 2004. In Roman Republican self-perception, the bad memory of kingship resulted in avoiding any appearance of regality. During the principate, the memory of the Republic was kept alive in the terminological framing of the new political settlement, cf. GOWING 2005; RICHARDSON 1991.

16 VITTINGHOF 1936, 9-12. The term damnatio memoriae was invented in the seventeenth century as a label for sanctions against the memory of someone who had been proclaimed 'enemy of the state' by official decree. However, the decree was flexible in terms of 'officiality' and practical use and effect: whether and how it worked out depended on the course of events. In the first century BCE, the hostis declaration (with serious legal consequences for the victim) was applied by the senate (cases are attested between 88-40 BCE), cf. ALLÉLY 2012. For the term damnatio memoriae, see VITTINGHOF 1936; FLOWER 2006, xix; DRIJVERS 2007, 8-10; VAN DEN HENGEL 2009, 321-328.
}

In her book The Art of Forgetting (2006) Harriet Flower warrants that this term is misleading, as it suggests a systematic practice of acting against the memory of convicts. In reality, however, sanctions against memory varied widely. Examples are a ban on the name of the victim, defacing statues and public monuments, erasure of his name in inscriptions, interdiction to mourn the deceased, celebration of the day of death and cursing the birthday of the victim and tearing down someone's house. ${ }^{17}$ Each of these measures had a different value and effect, for those applying them, for the victim, and for the surviving members of the victim's family, yet all symbolized the victim's loss of public prestige. In the early Republic, memory sanctions were a family matter, serving as an internal mechanism to keep dissidents out of public view and protect the family's position. In the course of time, however, when Rome's reach expanded, the memory of the leading men increasingly became a public affair, decided by those in power. Those with the position of highest authority would have the biggest say. This was still the case in the early Empire, with the major difference that the peer group was now falling behind the princeps who surpassed everyone else in auctoritas, as well as (notwithstanding Augustus' claim that this was not the case) in potestas.

Thus, whoever was in the position to decide how public memory was dealt with could write his version of history, and would be in a good position to bypass rivals. At the same time, the victims of memory sanctions had no opportunity to relate their side of the story, which troubles the reconstruction of a view beyond the image presented by the victor. Moreover, it cannot be denied that memory sanctions are signs of the victor's disagreement with the victim: in one way or another, condemned persons were perceived as a threat by those able to apply memory sanctions. How widely such disagreement was shared by others is impossible to define exactly. There is no case where memory sanctions have been carried out consistently by collective society; examples can be given of different groups responding differently to the memory of public figures. ${ }^{18}$ This highlights the subjectivity of memory sanctions, but also the collectificationary role they might have on behavior: an individual member of a certain group might follow behavior that was initiated by a few agents from the same group as a result of various social behavioral mechanisms, such as peer pressure or imitation. ${ }^{19}$

Another aspect of memory sanctions is that they served in retrospect, as a posthumous judgment, but also had a prospective and legitimizing claim. ${ }^{20}$ By presenting the rival as a dissident or enemy of the state who threatened society, one's own position would come out contrariwise, as savior of the state who would guard peace and stability. The following two cases illustrate the ways in which memory sanctions were applied in the competition over power

\footnotetext{
7 VITTINGHOFF 1936, 12-47; DRIJVERS 2007, 10-12. Cicero represents an example of a public persona whose house was demolished.

18 See below, note 51. In cases of condemnation of emperors for examples, (parts of their) names may be erased in epigraphic and papyrological sources; however, there are often many examples without erasure.

${ }^{19}$ https://www.britannica.com/science/collective-behaviour/Theories-ofcollective-behaviour.

${ }^{20}$ For the retrospective and prospective aspects of memory, see ASSMANN 1992, 70-71.
} 
between to political equals, in which it was important for the victor that his superiority was recognized over that of the victim and, by extension, that this result was also to the benefit of the common good.

\section{MEASURES AGAINST MEMORIAAS A POLITICAL INSTRUMENT. \\ Case 1: Augustus' 'memoires'}

The increasing political tensions in the late second century and the early first century BCE resulted in a series of civil wars in which measures against memoria were applied as a political instrument in an innovative way. ${ }^{21}$ During the Principate, the most important public place was held by the emperor. All kinds of events relating to the emperor or members of his family were publicly commemorated and sometimes even recorded in the calender.

The first case exemplifying the use of memory in political rivalry is provided by a monumental text illustrative for the transition from the Republic to the Principate: the Res Gestae Divi Augusti (RGDA). ${ }^{22}$ This monumental inscription, published in Rome and the provinces after Augustus died in $14 \mathrm{AD}$, preserves Augustus' reflection on his political career and achievements. ${ }^{23}$ The original version, inscribed in bronze and published on the outer walls of his mausoleum on the field of Mars in Rome, is lost, but the text has been preserved thanks to three (fragmentary) copies from the province of Galatia in modern Turkey. ${ }^{24}$ It contains a sublime example of self-presentation, in which Augustus explicitly states that he achieved his special position of power in a legitimate way and with the general consent of the Roman senate and people. Yet, Augustus' achievement in bringing peace and stability had neither been easy nor without violence. His unique power position was the result of a chaotic period of civil wars that had demanded many lives. The RGDA refer briefly and cautiously to this period in a way that illustrates how history is written by the victor. Augustus' primary audience were his contemporaries, but the monumental mis-en-scène of the inscription suggests that it was intended to endure. ${ }^{25}$ Indeed, the commemoration of his achievements might be considered exemplary for future leaders. ${ }^{26}$ It is impossible to

\footnotetext{
21 STEIN-HÖLKESKAMP 2013; FLOWER 2006, 93, 98. The outgoing Republic 121-43 BCE was a crucial phase for the development of memoria in the competition for power between influential politicians: cf. FLOWER 2006,111 , on the influence of Hellenistic practices and political developments within Rome as the most important causes for this. For the use of memory, for example through monuments, in the struggle for power between the generalstatesmen Gaius Marius and Lucius Cornelius Sulla, cf. Stein-Hölkeskamp (2013). Also FLOWER 2006, 86-98; EDER 2006; EVANS 1994; ELVERS 2006; KEAVENEY 2005²; SANTANGELO 2007.

22 The names adopted by Octavian during his life also reflect his political transformation. Born Gaius Octavius, his name was changed to Gaius Julius Caesar Octavianus after his adoption by Julius Caesar. From 40 BCE, he had the praenomen Imperator and he could refer to himself as divi filius. In 27 BCE the senate voted him the honorific title Augustus. Cf. KIENAST 19962, 61-63.

${ }^{23}$ On the historical embedding and a variety of interpretations of the RGDA, see COOLEY 2009, 30-41 and the bibliography in footnote 174). Cooley qualifies the text as exemplary for the 'unicity of Augustus', with special emphasis on the complex and levelled message the document contained and how that could have been perceived by various groups. See also ROWE 2013.

24 COOLEY 2009, 6-18.

25 The text was probably well known to the elite. See COOLEY 2009, 3-7 and 48-51.

${ }^{26}$ COOLEY 2009, 40-41.
}

do justice to the document's richness here, but a brief remark within the framework of memory strategies is in place.

Once he was adopted posthumously by his greatuncle Julius Caesar, the young Caesar manifested himself as an ambitious and strategic politician, who quickly made his way to the top. One of his first deeds was to avenge his adoptive father. He had the conspirators Gaius Cassius Longinus and Marcus Iunius Brutus declared as enemies of the state and defeated them together with Marc Antony in $42 \mathrm{BCE}$. In RGDA 1 Augustus states that he financed an army of his own, with which 'I set free the state, which was oppressed by the domination of a faction. ${ }^{27}$ In the second paragraph, Augustus puts it as follows: 'I drove the men who slaughtered my father into exile with a legal order, punishing their crime, and afterwards, when they waged war on the state, I conquered them in two battles. ${ }^{28}$ The victor's perspective is clearly recognizable in the language used. Augustus presents his father's murderers as the bad guys who were oppressors and a clear and present danger to the state (rem publicam a dominatione factionis oppressam; facinus bellum inferentis rei publicae). He himself acted according to the law (iudiciis legitimis), in this way saving the state and eliminating the mischief in battle (in libertatem vindicavi; eos in exilium expuli; vici bis acie).$^{29}$

Once Cassius and Brutus were defeated, the cooperation between Octavian and Marc Antony deteriorated, resulting in another civil war. Both parties used propaganda to damage their rival's reputation. Octavian certainly profited from Marc Antony's liaison with the Egyptian queen Cleopatra by presenting Marc Antony as being under the queen's spell and behaving in a way unsuited for a decent Roman man. What is more, he could present his conflict with Marc Antony as a foreign war against Cleopatra, which was more honorable than to fight a fellow Roman. References to the war against Marc Antony and Cleopatra are given in RGDA 25.2: 'All Italy swore allegiance to me voluntarily, and demanded me as leader of the war which I won at Actium'30, and in 27.1: 'I added Egypt to the rule of the Roman people.' ${ }^{31}$ Neither Marc Antony nor Cleopatra are referred to by name. The briefness of these formulations sharply contrasts with the historical importance of the events. The question arises how these examples represent a strategic attack on the enemy's memory, by means of not mentioning their names on purpose. ${ }^{32}$ Undoubtedly the events were so important for

\footnotetext{
${ }^{27}$... rem publicam a dominatione factionis oppressam in libertatem vindicavi. This and the following translations of the RGDA are by Thomas Bushnell: http://classics.mit.edu/Augustus/deeds.html (C) 199^).

${ }_{28}$ Qui parentem meum trucidaverunt, eos in exilium expuli iudiciis legitimis ultus eorum facinus, et postea bellum inferentis rei publicae vici bis acie.

${ }_{29}$ FLOWER 2006, 104-109, nicely explicates the confusion in this period and the importance of the point of view: Cassius and Brutus presented themselves as 'liberators' who cleared away the tyrant Julius Caesar. Cf. also COOLEY 2009, 114-115. COOLEY 2009, 48-50, about Tacitus' implicit criticism of Augustus' deeds in Annales 1.9-2.1. According to Tacitus, Augustus acted driven by personal ambition. In the RGDA Augustus states that the main reason for his action was the pietas for his father Julius Caesar.

${ }^{30}$ Iuravit in mea verba tota Italia sponte sua et me belli quo vici ad Actium ducem depoposcit.

${ }^{31}$ Aegyptum imperio populi Romani adieci.

32 For avoidance of the name Cleopatra as a memoria sanction in Syrian poleis, cf. VITALE 2013, 455-470. For avoidance of the name Marcus Antonius, but without the application of public memory sanctions as proposed by the senate, cf. FLOWER 2006, 116-121.
} 
Augustus that he added them to his account of achievements: restoration of the state was the fabulous result of events that marked his career. As Cassius, Brutus and Marc Antony had been declared hostes, it was only to be expected that their names would be passed over. Nevertheless, it can be stated that Augustus in fact very explicitly referred to his enemies. For his contemporaries the information was clear enough. Their memories of the events and the major players were reactivated by Augustus' account. ${ }^{33}$ By this significant nameskipping Augustus highlighted the contrast between his enemies' scandalous and his own correct behavior. Of course, this served to legitimize his own actions. Perhaps a difference in presentation can be noted in the place of reference: in the beginning, following the powerful opening statement about his own appearance on the political stage, the injustice of the murderers of Julius Caesar is presented. Even if Caesar had been perceived as behaving with royal tendencies, committing murder was morally wrong and was beyond Octavian's involvement as he had not yet played a political part. In settling this matter, Octavian could present his role as that of a pious avenger of his father. The rivalry with Marc Antony, however, was different, as Octavian now was a political player. His own involvement in this civil war was less easy to defend, even if Marc Antony was portrayed as behaving amorally towards the Roman state. This may be the reason why the reference to Egypt's annexation is so modest in this text. Moreover, it is rather presented as a foreign conquest.

With the fall of Alexandria and Marc Antony's suicide in 30 BCE the civil wars came to an end. An unprecedented accumulation of power and honors was awarded to Octavian, who in 27 BCE received the honorific name Augustus. His victory was publicly broadcast all over the empire and his saving the Roman state from dissolution and bringing peace to the empire became a central theme of Augustus' image. The RGDA thus both marks an end point and a new beginning in Roman history. After his death it became only all too clear how solid the foundation of his own memory was, which Augustus himself had created during his lifetime. ${ }^{34}$ His imperial successors would build on this, consolidating and expanding their power position. ${ }^{35}$

This example clearly shows how masterfully Augustus used the memory space allowed to (and controlled by) him by presenting the memory to himself in a positive way and devaluating the memory of his enemies. Furthermore, the RGDA illustrates a clear step in the direction of monopolization of the public memory space by Augustus'

\footnotetext{
33 Tacitus, Ann. 3.76, describes the funeral of Junia, the sister of Brutus and wife to Cassius. Customarily wax masks (imagines) of illustrious family members were carried in the funeral procession. The masks of Cassius and Brutus were absent, resulting from their defeat and defamation by Octavian. Interestingly, Junia treated Augustus with a comparable tactic: she included many notables in her will in praising words, but passed over Augustus in silence. Tacitus sketches the effect of this silent protest: '... in disposing of her great wealth she mentioned nearly every patrician of note in complimentary terms, but omitted the Caesar....The effigies of twenty great houses preceded her to the tomb... But Brutus and Cassius shone brighter than all by the very fact that their portraits were unseen.'

34 The lasting impression of Augustus is still recognizable in the western calendar. STUTTARD/MOORHEAD 2012, 177; RÜPKE 1995, 184-185, 383.

35 Thanks to his deification, Augustus obtained a place in Rome's religious calendar. In political respect, he became the model to be followed by his successors.
}

and his successors, the emperors of the Roman empire. As a consequence of the new order the space for self-presentation by the traditional senatorial elite became less. The princeps would outshine the senate. Yet this would not make a princeps an absolute mnemonic hegemon: only during his lifetime mnemonic hegemony would be his prerogative. For Augustus, it turned out well, just as for the next emperor to be discussed.

\section{Case 2: From fratricide to franchise. Caracalla and the memory of Geta}

The second example involves the dramatic events following the death of the emperor Septimius Severus in AD 211. This example shows how an emperor himself was actively involved in the destruction of the memory of his fellow emperor. Septimius Severus had elevated both his sons to the position of Augustus, leaving them in an equal power position. ${ }^{36}$ His paternal advice to his sons that they should live in harmony soon proved an unachievable goal. The thirdcentury historiographers Cassius Dio and Herodian describe how the brothers continuously were at loggerheads. Finally, Caracalla had his brother Geta cruelly murdered in their mother's arms. ${ }^{37}$ Various measures aimed at Geta's public memory were immediately decreed:

'Vast numbers of citizens had been falsely accused, not merely those who had sent letters to his brother or had brought him gifts, either when he was still Caesar or when he had become emperor, but even the others who had never had any dealings with him. Indeed, if anyone so much as wrote the name Geta or even uttered it, he was immediately put to death. Hence the poets no longer used it even in comedies; and in fact the possessions of all those in whose wills the name appeared were confiscated....He exhibited his hatred for his dead brother by abolishing the observance of his birthday, and he vented his anger upon the stones that had supported his statues, and melted down the coinage that displayed his features. And not content with even this, he now more than ever practised unholy rites, and would force others to share his pollution, by making a kind of annual offering to his brother's Manes. ${ }^{38}$

Dio's account is confirmed by a variety of other sources: examples of damage to Geta's image and name are found in statues, inscriptions, coins, papyri, and even in a painted wooden panel containing a family portrait of Septimius Severus, with his wife Julia Domna and their sons Caracalla and Geta, where Geta's face has been washed away. ${ }^{39}$ There can hardly be doubt that Caracalla wished to obliterate his brother's memory as thoroughly as possible. This assumption is corroborated especially by two Greek papyri found in Egypt. One preserves an edict issued by the prefect of Egypt, in which he probably announced the condemnation of Geta and his memory. Unfortunately, the fragmentary state of the papyrus obfuscates the reading and understanding of the text, but the key terms that can be made out are $\mu v \eta$ $\mu \eta$ ('memory', 'remembrance') in line 7, and two opposite words in lines 4 and 5 that are likely ${ }^{36}$ KIENAST 1996², 162-165 (Caracalla) and 165-167 (Geta)).

7 Cassius Dio 78. 1-2; Herodian 4.1-4.

${ }^{38}$ Cassius Dio 78. 12. 5-6.

39 KRÜPE 2011; for the papyrological evidence for Geta's condemnation, see DE JONG 2006, 136-173 and appendix 4. DE JONG 2007, 95-111. 
to have referred to Geta and Caracalla respectively..$^{40}$ Line 4 mentions 'most impious', probably in relation to Geta and contrasting with the qualification 'most pious' in line 5, probably connected to Caracalla. Possibly Geta's name was not mentioned at all, being circumscribed instead. Notably, the political conflict is formulated in terminology that semantically has divine connotations.

The second papyrus text is also interesting for this combination of politics and the ascription of the events to divine interference. The document is known as the Constitutio Antoniniana, the imperial decree issued by Caracalla that granted Roman citizenship to a considerable number of free inhabitants of the Roman empire. ${ }^{41}$ Again, the text is fragmentary, but enough of the writing is preserved to accept the proposed identification. A connection to the gods is recognizable in the first lines, where the goal of the grant is stated: as many people as possible should be joining in thanking 'the immortal gods for preserving me in such [danger?]'. ${ }^{42}$ Apart from this reason stated by Caracalla himself, there has been much speculation about his motives to grant the Roman citizenship. ${ }^{43}$ More Roman citizens might have increased the incoming amount of tax money, as Dio explained Caracalla's move. Others have explained the act as a formalization of a process of social and cultural acculturation, resulting in an increased Romanitas within the provinces. At any rate, a concomitant explanation is Caracalla's wish to justify the fratricide. In the text, Caracalla presents himself as the victim of an impious deed and underlines his own piety. This framing, already familiar from BGU XI 2056, left no doubt about the affair: Caracalla had had no choice but to act in response to his brother's attack. This self-defense was successful because it had been supported by the gods. The only adequate way to thank them was to involve a substantial number of people in the worship of the gods. This was achieved by giving the appointed group of beneficiaries a status upgrade. Detailed knowledge of the general popular response to the imperial grant is lacking, but evidence hints at an enthusiastic reception of the 'divine gift' $(\theta \varepsilon \tilde{\alpha} \alpha \delta \omega \varepsilon \alpha \dot{)})$ by at least some beneficiaries. ${ }^{44}$ For this group, the grant of Roman citizenship may have been a fine maneuver to detract attention from Caracalla's guilt in the death of his brother. As the new sole ruler Caracalla was in the position to manage the memory of his brother. As stated, the measures proclaimed by Caracalla were severe. That is partly to be explained from personal hatred, but given the fact that Geta had been an equally legitimate emperor there is certainly a political aspect to this. In dealing with Geta's memory Caracalla tried to justify his own deed in pious terms and to underline his position as the only legitimate emperor. As long as he held this position, Caracalla could act as a mnemonic hegemon. As a result, history remembers Geta for no other reason than the personal attack that he

\footnotetext{
${ }_{40}$ BGU XI 2056 (CE 212, Alexandria). The editor of this text assumes on p. 78 that this document is a Greek paraphrase of the original Latin senatorial

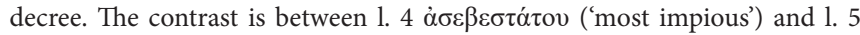

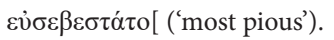

${ }_{41}$ P.Giss. I 40 (CE 215, Apollonopolitis Heptakomias). HEKSTER 2008, 45-55.

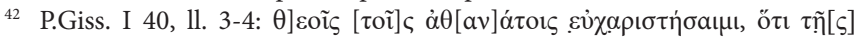

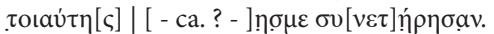

${ }^{43}$ HEKSTER 2008, 45-55.

${ }^{44}$ BURASELIS 1989.
}

and the memory of him suffered by his brother's resolute action.

\section{EMPERORS IN COLLECTIVE MEMORY}

As stated earlier, only during his lifetime mnemonic hegemony would be the emperor's prerogative. However, what happened to his own memory was out of his control.

Whereas in the Republic the maiestas of the state was an important commonality for the collective, during the principate the princeps increasingly came to embody the state. ${ }^{45}$ The emperor became an important symbol of the empire and the object of the collective memory of the Roman empire, both during his reign and after death. Imperial images and titles were widely dispersed throughout the empire by means of various textual and visual media, such as statues, paintings, coins, inscriptions and written documents. ${ }^{46}$ Besides these visible references to the emperor, the subjects were also involved in imperial celebrations.

In the Republican political system the nobiles were in office for a restricted period, so that no one would gain too much power. During the principate, however, the emperor had the highest authority as long as he was recognized as emperor. From the very start of the imperial system dynastic succession was an important principle. ${ }^{47}$ This had an impact on the memoria of emperorship in different directions. The emperorship as a political system became embedded in the collective memory, and as such it also functioned as the expected system of the future. ${ }^{48}$ Past emperors were a point of reference for their successors. Hence, they were 'judged' by their survivors, be they emperor, senators, soldiers, individuals. In most cases one of two options was applied: emperors were deified or they could be subject to memory sanctions. ${ }^{49}$ Whether emperors were commemorated positively or negatively depended per case and context. This can be ascribed to the different responses given by different groups, which in itself depended on these groups' relations with and expectations of the emperor. In spite of its decreased political power, the senate constituted a dominant factor in the evaluation of an emperor, and the senatorial view might have differed from the perspective of the Roman people or of the soldiers. ${ }^{50}$ Nevertheless, whether or not memory sanctions were carried out could also depend on the power balance and negotiation between the successive emperor, the senate, and other groups such as soldiers and inhabitants of Rome. ${ }^{51}$ In other words, in cases when emperors were

\footnotetext{
5 The way in which his new power position was presented in Republican terminology is a meaningful example of the importance of memory in constructing history. Cf. Gowing $\left(2005^{2}\right)$.

46 ANDO 2000.

47 WOOLF 2012, 169-173; HEKSTER 2014; HEKSTER 2015.

48 ASSMANN 1992, 70-71; HEKSTER 2015, 323.

49 GRADEL 2002, 286-288. Although both practices are commemorative strategies, deification and condemnation were not exact opposites. Cf. DE JONG 2006, 173; VAN DEN HENGEL 2009, 335.

50 An example of a different reaction by various groups is provided by the description of these by Suetonius, after the death of Domitian. Suetonius, Life of Domitian 23.1: 'The people received the news of his death with indifference, but the soldiers were greatly grieved and at once attempted to call him deified...The senate on the contrary was so overjoyed... that his shields and images were torn down before their eyes and were smitten upon the ground; finally they passed a decree that his inscriptions should everywhere be erased, and all record (memoria) of him obliterated.'

1 For example, when Claudius succeeded Caligula and Antoninus Pius
} 
replaced, there was not always a clear mnemonic hegemon, but different stakeholders could try to implement their desired course of action. Although it remains unclear to what degree there was collective consensus about the judgment, the opinion of the most powerful would prevail in the public memory space and hence influence how he would be incorporated in public commemoration in the short term and, with time and if no counter actions were undertaken, in collective memory. This could have a longer-term effect for the deceased emperor, as the application of either honours or memory sanctions would contribute in evoking a positive or negative image of him. ${ }^{52}$

\section{INTENTIONS AND EFFECTS}

One last matter to be discussed is whether memoria sanctions had an exemplary effect and whether they served as a warning against unrightful behavior? Here, too, the answer is not straightforward, but depends on the view of the condemning party and the (intended) audience, which at the moment a condemnation was decided had no knowledge about the future course of events. To some degree, several cases can be interpreted as broadcasters of a prohibitory message. If senatorial condemnation of the memory of one of their peers was a response to the victim's threatening or damaging of the state, the message was that future senators should not imitate such behavior. This explanation can be given for some of the incidents encountered in the early Republic, but also to the famous case of Gnaeus Calpurnius Piso, whose memory was condemned after he committed suicide in AD 20.53 He was accused of having had a hand in the death of Germanicus, the popular adopted son of the emperor Tiberius in AD 19. Thanks to a copy of the official senatorial decision, the sanctions that were made against his memory have come down to us. His case exemplifies how senators reminded themselves better to avoid conflicts with the emperor and his family and also indicates how in this case the negotiation over memory space between emperor and senate was favorable for the emperor due to the senate's agency. This is telling for the balance of power between emperor and senate. In a circumspect way, the case of the emperor Domitian, whose memory was condemned by the senate, may have been used by Pliny when he addressed a panegyric to the emperor Trajan to serve as an anti-example for imperial behavior. Pliny clearly outlined what kind of emperor he (and the senate) expected Trajan to be - the contrast with his condemned predecessor can hardly have escaped anyone. ${ }^{54}$ However, did these kinds of anti-examples have the desired effect? Even if the prospect of memoria sanctions theoretically might have functioned as a deterrent for bad behavior for future leaders, in practice it is doubtful

succeeded Hadrian. In both cases the successor refused a radical application of memory sanctions.

52 These negative or positive associations may result from the original combination of legal and moral judgment that preceded official condemnation. For the connection between memory condemnation and infamity see VAN DEN HENGEL 2009, 328.

53 FLOWER 1998, 155-187; FLOWER 2006, 132-138; DRIJVERS 2007, 7-8. 54 Throughout the Panegyric, Domitian is mostly referred to in abusive or covert terms and sharply contrasted with the laudatory references to Trajan. However, Pliny's intended effect on Trajan in the Panegyric is debated. Cf. KÜHN 1985; ROCHE 2011 and especially the contributions by INNES 2011 and MANUWALD 2011 (both in ROCHE 2011). whether this really worked: it is improbable that a potential posthumous disapproval would keep a ruler in check. ${ }^{55}$ Of course this has to do with the leader's power position: as long as he was on top of things, his memory was safe. Hence, in case of an emperor it can be assumed that during his reign senatorial opinion probably - and in at least some cases certainly - did not play a decisive role for imperial behavior. Moreover, whether an emperor's memory was condemned or not could even depend on the senate's incapability to act. The examples of Caligula, Hadrian and Commodus illustrate this. In these cases, the senate wished to apply memory sanctions, but successive emperors thwarted the senate's plan. ${ }^{56}$ This point leads to another observation about the importance of imperial memoria. It provides insight in how a successor perceived his predecessor in the imperial line. As emperorship became an institution, continuation of the line of emperors became the norm. However, succession not always went smoothly. Indeed, it is significant that in the first century of the principate in two cases where an emperor suffered condemnation by senatorial verdict, that of Nero and of Domitian, the dynastic line of which they were part came to an end. Hence, it is clear that the next emperor's attitude towards his predecessor's memory was often in consultation with, but sometimes against, senatorial opinion. ${ }^{57}$

The last point of notice is the application of punitive measures against memory in the civil wars caused by rivalry for imperial power during the first three centuries of the principate. In the years 68-69, 193-197, 217-218, and between 235-285 CE numerous examples are found of measures against the memories of deceased emperors. In some cases, these were the last emperors of a dynasty, in others, they had malfunctioned in senatorial perception or were considered as usurpers. The application of memory sanctions in these cases befits the idea that these emperors were enemies of the state, whose despicable behavior was underlined by defaming their memory. Again, the definition of usurper depended highly on the outcome of the battle for power. In the mid-third century, many imperial reigns were only short-lived. ${ }^{58}$ It is difficult to find a systematic application of memory sanctions in dealing with the deceased emperors and sometimes the evidence is contradictory. This may be ascribed to the chaos of the time and to the differentiated responses to the outcomes. Furthermore, given the quick succession of emperors, it can be assumed that imperial output in words and images by public media was relatively low compared to the first and second centuries, where most emperors ruled for more than a decade. So, not only was there less material per emperor to be attacked, but also was there little occasion to think thoroughly of how to position oneself in relation to one's predecessor. Condemnation might have been the most expected response in case of overthrowing the predecessor, but in the turbulence of the mid-third century emperors rather needed their attention to survive.

\footnotetext{
5 For example, Caligula, Nero, Domitian, Hadrian, Commodus and Heliogabalus did not act according to the wishes of the senate.

${ }^{56}$ DE JONG 2006, 136-173.

Commodus also presents the end of a dynasty; nevertheless, Septimius Severus connected himself tightly to this dubious predecessor, presenting himself as his brother. DE JONG 2006, 136-137; VAN DEN HENGEL 2009, 318-319.

${ }^{58}$ Especially in the period 235-284. See for instance JOHNE 2008.
} 
Consequently, their focus was on maintaining themselves in the present, rather than developing policy about how to deal with the (immediate) past. It seems that this shows another aspect of mnemonic hegemony: its functioning depended on practical circumstances.

\section{CONCLUSION}

The importance of memoria in Roman political culture and the intimate relation between memoria and measures against memoria in the struggle for and legitimation of power cannot be underestimated. Due to Roman concern with reputation and memory and resulting from sociopolitical developments in the late Republic personal power politics were increasingly becoming a collective matter. Consequently, individual memoria was politicized and made a collective issue, and memory control became instrumental in the competition for power. Whoever was in the dominant position could wield 'mnemonic hegemony'. As falling prey to oblivion was shameful and disgracing to Roman aristocrats it is easily comprehensible why measures against reputation and memory should be understood as a hard attack on their very identity and essence as Roman citizens. This effect is the more highlighted by the fact that memory sanctions were often applied posthumously. Besides this, demeaning an opponent's memory could function to elevate one's own image.

The more prominent one was in public life, the higher the chance that one's memory would be upheld. On the other hand, public prominence also implied a risk, as the examples of conscious interferences targeting the memoria of leading men have demonstrated. It is self-evident that the resulting historical image is strongly defined by the victor, and that it is easier to evaluate his position of power and motives than to gauge the guilt of the victim. The concept of mnemonic hegemony constitutes a key to understanding mechanisms of public commemoration of prominent Romans. A concomitant aspect is the way in which the personal is made collective, fitted with a moral jacket.

During the principate, when the emperor embodied the memory of the empire, sanctions against an emperor's memoria served as a negative verdict that was given by the senate. However, emperors could also give their own verdict upon their predecessor by choosing to present themselves in his line or by distancing themselves from predecessing (or fellow) emperors. Still, emperors did not have the last word: what verdict would be given to their own memoria was beyond their power.

The examples discussed demonstrate the importance of memory, the context-bound character of each individual case, and the strategic use of memory in Roman political culture, by those who were in the most powerful position also to dictate the messages displayed in words and images. Whether and how memory sanctions were inflicted varied per case. In all cases, several factors to a greater or lesser degree contributed to the way in which memory sanctions were applied. If (political) rivalry and emotions are intertwined and recurrent motives which could result in condemnation of an enemy's memory, the decision to maltreat memory had the character of a verdict that was not only legally corroborated, but also had moral implications of disapproving and delegitimizing the victim, while approbating and legitimizing the victor. Correlation between the importance and public visibility of the victim and the scale on which measures were taken can certainly be assumed, but in the end condemnation was a matter of personal decision or negotiation between several parties. Still, as the cases discussed aimed to show, the final result of administering posthumous memory sanctions is the same. Measures against memoria were not so much aimed at removal of rivals from collective memory, but rather at public denial of their virtue. Acknowledging such a serious fault of any member of the Roman political body would be shameful for the condemned and made him a social outcast. Consequently, the victims of memory sanctions obtained a place in collective memory in a negative way as dissident and anti-social individuals, whereas the winners in the battle for power could single themselves out in their own construction of the present.

The condemnation of memory of rivals for power within the imperial system contains an unmistakable message about the balance of power. It is strongly dependent on the victorious emperor, the framing of the victim's immoral behavior towards the state, the seemingly and deliberately established timing of the victor's communication, and ultimately, the further course of history. ${ }^{59}$

\section{ACKNOWLEDGEMENTS}

I wish to thank Olivier Hekster and Alessandro Maranesi for reading and commenting on an earlier draft of this article.

\section{REFERENCES}

\section{ALLÉLY 2012}

Allély, A., La déclaration d'hostis sous la République romaine (Bordeaux: Ausonius).

\section{ANDO 2000}

Ando, C., Imperial Ideology and Provincial Loyalty in the Roman Empire (Berkeley: University of California Press)

\section{ASSMANN/CZAPLICKA 1995}

Assmann, J./Czaplicka, J., Collective Memory and Cultural Identity, New German Critique 65, 125-133. Original publication. In: Assmann, J./Hölscher, T. (1988), Kultur und Gedächtnis (Frankfurt am Main: Suhrkamp), 9-19.

ASSMANN/WEINBERG/WINDISCH 1998

Assmann, A./Weinberg, M. /Windisch, M. (eds.) 1998, Medien des Gedächtnisses (Stuttgart-Weimar: Metzler).

\section{ASSMANN 2008}

Assmann, J., Communicative and Cultural Memory. In: Erll, A./Nünning, A. (eds.), Cultural Memory Studies. An International and Interdisciplinary Handbook (Berlin-New York: Walter de Gruyter), 109-118.

\section{BURASELIS 1989}

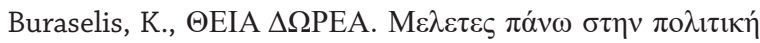

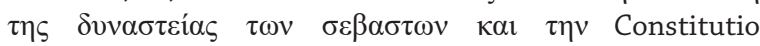
Antoniniana (Athens). Translated in 2007 as Theia dōrea: das göttlich-kaiserliche Geschenk: Studien zur Politik er Severer und zur Constitutio Antoniniana (Wien: Austrian Acadamy of Science Press).

59 This also aligns well with the development in localization of power. HÖLSCHER 2001, 184, points to the importance of locality in the institutionalization of memory: 'An signifikanten Orten ergeben sich spezifische Situationen des Gedächtnisses, die dadurch Ihre Verfestigung und Verstetigung erhalten'. 


\section{COOLEY 2009}

Cooley, A.E., Res Gestae Divi Augustis. Text, Translation, and Commentary (Cambridge: Cambridge University Press).

\section{DRIJVERS 2007}

Drijvers, J.W., Damnatio memoriae in het antieke Rome. Een impressie, Groniek, Historisch Tijdschrift 7-20.

EDER 2006

Eder, W., Cornelius' [I 90]. In: Cancik, H./Schneider, H. (eds.), Brill's New Pauly. Antiquity Volumes. Available at: http://referenceworks.brillonline.com/entries/brill-s-newpauly/cornelius-e305350.

ELVERS 2006

Elvers, K.-L., Marius. In: Cancik, H./Schneider, H. (eds.), Brill's New Pauly. Antiquity Volumes (Brill Online). Available at: http://referenceworks.brillonline.com/entries/brill-snew-pauly/marius-e723970.

EVANS 1994

Evans, R.J., Gaius Marius: A Political Biography (Pretoria: University of South Africa).

FLOWER

Flower, H.I., Ancestor Masks and Aristocratic Power in Roman Culture (Oxford: Clarendon Press)

FLOWER

Flower, H.I., Rethinking "Damnatio Memoriae": The Case of Cn. Calpurnius Piso Pater in AD 20, Classical Antiquity 17.2, 155-187.

FLOWER 2006

Flower, H.I., The Art of Forgetting. Disgrace and Oblivion in Roman Political Culture (Chapel Hill: The University of North Carolina Press).

GALINSKY 2014

Galinsky, G.K., Memoria Romana: Memory in Rome and Rome in Memory (Ann Arbor, Michigan: University of Michigan Press).

GALINSKY/LAPATIN 2015

Galinsky, G.K./Lapatin, K.D.S. (eds.), Cultural Memory in the Roman Empire, Los Angeles: The J. Paul Getty Museum. Gowing, A.M., Empire and Memory: The Representation of the Roman Republic in Imperial Culture (Cambridge: Cambridge University Press)

GOWING 2005

Gowing, A.M., Empire and Memory: The Representation of the Roman Republic in Imperial Culture (Cambridge: Cambridge University Press).

GRADEL 2002

Gradel, I., Emperor Worship and Roman Religion (Oxford: Oxford University Press).

\section{HEKSTER 2008}

Hekster, O.J., Rome and its Empire, AD 193-284 (Edinburgh: Edinburgh University Press).

HEKSTER 2014

Hekster, O.J., Son of two fathers? Trajan and the adoption of emperorship in the Roman Empire, The History of the Family 19.3, 380-392.

HEKSTER 2015

Hekster, O.J., Emperors and Ancestors. Roman Rulers and the Constraints of Tradition (Oxford: Oxford University Press).

VAN DEN HENGEL 2009

Hengel, L. van den, Imago. Romeinse keizerbeelden en de belichaming van gender (Hilversum: Verloren).

HÖLSCHER 2001

Hölscher, T., Die Alten vor Augen. Politische Denkmäler und öffentliches Gedächtnis im republikanischen Rom. In: Mele ville, G. (ed.) Institutionalität und Symbolisierung. Verstetigungen kultureller Ordnungsmuster in Vergangenheit und Gegenwart (Köln-Weimar-Wien: Böhlau Verlag), 183-211.

\section{INNES 2011}

Innes, D.C., The Panegyricus and Rhetorical Theory. In: Roche, P. (ed.), Pliny's Praise: The Panegyricus in the Roman World (Cambridge: Cambridge University Press), 69-84.

\section{DE JONG 2006}

Jong, J.H.M. de, Emperors in Egypt. The Representation and Perception of Roman Imperial Power in Greek Papyrus Texts from Egypt, AD 193-284 (Dissertation, Radboud University Nijmegen).

DE JONG 2007

Jong, J.H.M. de, Propaganda or Pragmatism? Damnatio memoriae in third-century papyri and imperial representation, in: Benoist, S. (ed.), Cahiers du Centre Gustave-Glotz, 'Mémoire et Histoire II. Condamnation des Identités du Principat á l’Empire chrétien (Metz) 95-111.

JOHNE 2008

Johne, K.-P. (ed.), Die Zeit der Soldatenkaiser, (Berlin: Akademie Verlag).

\section{KEAVENEY 2005}

Keaveney, A.P., Sulla. The Last Republican (London - New York: Routledge).

KIENAST 1996

Kienast, D., Römische Kaisertabelle. Grundzüge einer römischen Kaiserchronologie (Darmstadt: WBG)

KLEIN 2000

Klein, K.L., On the emergence of 'memory' in historical discourse, Representations 69, 127-150.

KRÜPE 2011

Krüpe, F., Die Damnatio memoriae. Über die Vernichtung von Erinnerung. Eine Fallstudie zu Publius Septimius Geta (198211 n. Chr.) (Gutenberg: Computus Druck Satz \& Verlag).

KÜHN 1985

Kühn, W., Plinius der Jüngere - Panegyricus (Darmstadt).

LÖHR 2006

Löhr, W.A., Portrait Gallery. In: Cancik, H./Schneider, H. (eds.), Brill's New Pauly. Antiquity Volumes. Available at: http://referenceworks.brillonline.com/entries/brill-s-newpauly/portrait-gallery-ct-e15203950.

MANUWALD 2011

Manuwald, G., Ciceronian Praise as a Step towards Pliny's Panegyricus. In: Roche, P. (ed.), Pliny's Praise: The Panegyricus in the Roman World (Cambridge: Cambridge University Press), 85-103.

MESOUDI/WHITEN/LALAND 2004

Mesoudi/A., Whiten, A./Laland, K.N., Is human cultural evolution Darwinian? Evidence Reviewed from the Perspective of the Origin of Species, Evolution 58.1, 2004, $1-11$.

MOLDEN 2015

Molden, B., Resistant pasts versus mnemonic hegemony: On the power relations of collective memory, Memory Studies 9.2, 125-142.

NAIRNE/PANDEIRADA/THOMPSON 2008

Nairne, J.S., Pandeirada, J.N.S., Thompson, S.R., Adaptive Memory. The Comparative Value of Survival Processing, Psychological Science 19.2, 176-180.

RICHARDSON 1991

Richardson, J.S., Imperium Romanum: Empire and the Language of Power, Journal of Roman Studies 81, 1-9.

RICOEUR 2004

Ricoeur, R., Memory, History, Forgetting (Chicago-London: The University of Chicago Press)

ROCHE 2011

Roche, P. (ed.), Pliny's Praise: The Panegyricus in the Roman ROWE 2013 
Rowe, G., Reconsidering the Auctoritas of Augustus, Journal of Roman Studies 103, 1-15

\section{RÜPKE 1995}

Rüpke, J., Kalender und Öffentlichkeit: die Geschichte der Repräsentation und religiösen Qualifikation von Zeit in Rom (Berlin: Walter de Gruyter).

SANTANGELO 2007

Santangelo, F., Sulla, the Elites and the Empire: A Study of Roman Policies in Italy and the Greek East (Leiden-Boston: Brill).

SEGESTEN/WÜSTENBERG 2017

Segesten, A.D./Wüstenberg, J. Memory studies: The state of an emergent field, Memory Studies 10.4, 1-16.

STEIN-HÖLKESKAMP 2013

Stein-Hölkeskamp, E., Macht, Memoria und Monumente: Marius, Sulla und der Kampf um den öffentlichen Raum, Klio - Beiträge zur Alten Geschichte 95.2, 429-446.

\section{SUTTON 2012}

Sutton, J., Memory. In: Zalta, Edward N. (ed.), The Stanford Encyclopedia of Philosophy, http://plato.stanford.edu/ archives/win2012/entries/memory/.

STUTTARD/MOORHEAD 2012

Stuttard, D./Moorhead, S., 31 BC: Antony, Cleopatra and the TAMM 2013 Fall of Egypt (British Museum Press).

Tamm, M. Beyond History and Memory: New Perspectives in Memory Studies, History Compass 11.6, 458-473.

\section{TOTA/HAGEN 2015}

Tota, A.L./Hagen, T., Routledge International Handbook of Memory Studies (London-New York: Routledge).

\section{TUMBLETY 2013}

Tumblety, J. (ed.), Memory and History: Understanding Memory as Source and Subject (London-New York: Routledge).

\section{TULVING/CRAIK 2000}

Tulving, E./Craik, F.I.M. The Oxford Handbook of Memory (Oxford-New York: Oxford University Press).

\section{VARNER 2000}

Varner, E.R. (ed.), From Caligula to Constantine. Tyranny \& Transformation in Roman Portraiture (Atlanta, Georgia).

\section{VARNER 2004}

Varner, E.R., Mutilation and Transformation. Damnatio Memoriae and Roman Imperial Portraiture, Monumenta Graeca et Romana X (Leiden: Brill).

\section{VITALE 2013}

Vitale, M., Kleopatra auf einer Inschrift aus Ägypten und auf Münzprägungen syrischer Poleis: Das Schweigen der Erinnerungsmedien nach Actium? Klio - Beiträge zur Alten Geschichte 95.2, 455-470.

\section{VITTINGHOF 1936}

Vittinghof, F., Der Staatsfeind in der römischen Kaiserzeit. Untersuchungen zur "damnatio memoriae" (Berlin: Speyer).

\section{WOOLF 2012}

Woolf, G., Rome. An Empire's Story (Oxford-New York: Oxford University Press). 